This item was submitted to Loughborough's Research Repository by the author.

Items in Figshare are protected by copyright, with all rights reserved, unless otherwise indicated.

\title{
Life-cycle assessment of a $100 \%$ solar fraction thermal supply to a European apartment building using water-based sensible heat storage
}

\section{PLEASE CITE THE PUBLISHED VERSION}

http://dx.doi.org/10.1016/j.enbuild.2010.12.029

PUBLISHER

(C) Elsevier

VERSION

AM (Accepted Manuscript)

\section{LICENCE}

CC BY-NC-ND 4.0

\section{REPOSITORY RECORD}

Simons, Andrew, and Steven K. Firth. 2019. "Life-cycle Assessment of a 100\% Solar Fraction Thermal Supply to a European Apartment Building Using Water-based Sensible Heat Storage". figshare.

https://hdl.handle.net/2134/8294. 
This item was submitted to Loughborough's Institutional Repository (https://dspace.lboro.ac.uk/) by the author and is made available under the following Creative Commons Licence conditions.

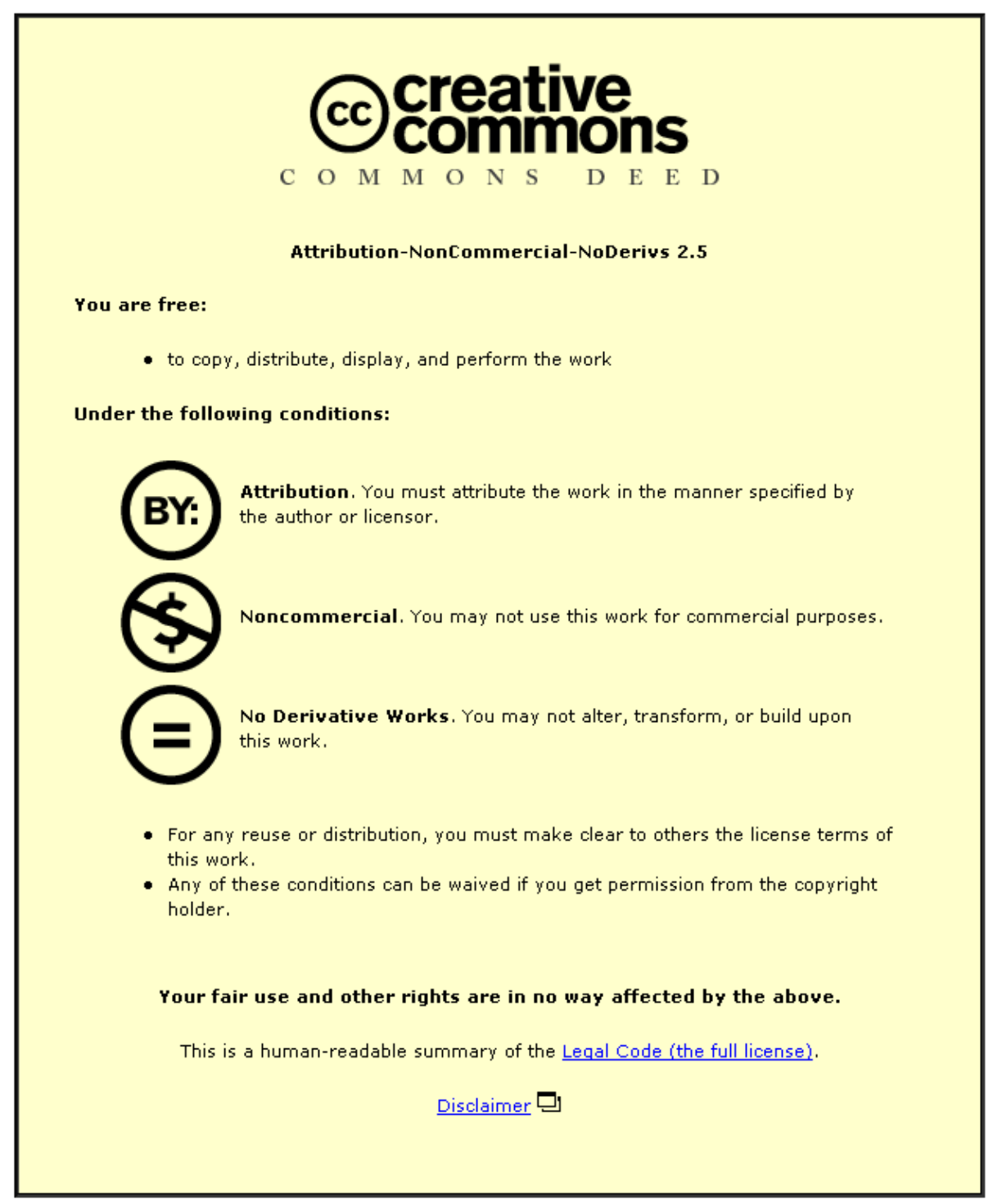

For the full text of this licence, please go to: http://creativecommons.org/licenses/by-nc-nd/2.5/ 


\title{
Life-cycle assessment of a $100 \%$ solar fraction thermal supply to a European apartment building using water-based sensible heat storage
}

\author{
Andrew Simons ${ }^{1, *}$, Steven K Firth ${ }^{2}$ \\ ${ }^{1}$ Paul Scherrer Institute (PSI), 5232 Villigen, Switzerland. \\ ${ }^{2}$ Dept. of Civil and Building Engineering, Loughborough University, LE11 3TU, UK.
}

\begin{abstract}
Providing $100 \%$ of a building's heating and hot water using a solar thermal system in a European climate has been shown to be both practically feasible and functionally successful for a new apartment building in Switzerland. The research conducted a life cycle assessment of the solar thermal system and compared the results with an air-source heat-pump, ground-source heat pump, natural gas furnace, oil furnace and a wood-pellet furnace. Using a range of lifetime scenarios it was found that the solar thermal system displays potentially significant advantages over all other systems in terms of reductions for purchased primary energy (from 84 to 93\%) and reductions in GHG emissions (from 59 to $97 \%$ ). However, due to the heavy industrial processes and the particular metals used in manufacturing, the solar thermal system was shown to have a higher demand for resources which, in relation to the natural gas system, can be by a factor of almost 38 . Potential impacts on ecosystem quality were marginally worse than for the heat-pump and fossil fuel systems due to resource use impacts whilst potential human health impacts were similar to the heat pump systems but better than the fossil and biomass fuelled systems.
\end{abstract}

Key words: Life cycle assessment; seasonal thermal energy storage; 100\% solar fraction.

*Corresponding author. Tel.: +41 (0)56 310 2007. E-mail address: andrew.simons@psi.ch 
In the 1990s the theory of a 2000 Watt (W) society was developed which sought to quantify sustainability [1-2]. $2000 \mathrm{~W}$ was determined to represent a future per capita consumption rate of primary energy associated with the goods and services for an inhabitant of the industrialised world, and which would achieve equality in terms of sustained global consumption. This continuous consumption rate equates to an annual energy demand of $63.1 \mathrm{GJ}$ per capita. The theory requires this to consist of a maximum of 500W from fossil fuels and a minimum of 1500W from non-fossil sources. It was determined that achieving this would lead to the stabilisation of atmospheric $\mathrm{CO}_{2}$ concentrations whilst allowing for human comfort, prosperity and economic growth. Although $2000 \mathrm{~W}$ does represent average worldwide demand, it hides huge inequality in which individual country averages range from approximately 500W per person for most developing countries to around $12,000 \mathrm{~W}$ for the highest users. The actual average consumption level in Europe is $6000 \mathrm{~W}$ where $80 \%$ is fossil fuel based [3]. In Switzerland, from an overall level of about 5100W per person, around 1590W $(31 \%)$ is needed for the construction, operation and maintenance of residential buildings. According to Koschenz et al. [4] the use of fossil fuels in heating systems accounts for around $750 \mathrm{~W}$ of this and must therefore be drastically reduced if the target level for fossil fuel use is to be achieved.

In continental Europe, a domestic building constructed according to advanced standards can reduce the energy demand for space heating by $70 \%$ to $80 \%$ in comparison with that of the average building in 2005 [5]. In Switzerland, achieving the Minergie-standard [6] requires an overall energy demand of just $40 \%$ that of the current building standards [7]. Smeds and Wall [8] determined that even in northern European climates the energy demand from space heating can be reduced by more than $80 \%$ in comparison with homes built after 2001. Passive design features can also be incorporated so that interior temperature fluctuations are reduced, as well as profiting from direct solar radiation. As both building efficiencies and the technical feasibility of alternative heating systems increase then supplying the remaining demand from sources previously considered as insufficient (e.g. solar thermal) can also be taken into the decision process.

If well insulated domestic buildings in central Europe are fitted with water-based solar heating systems which have the capacity to build up and store thermal energy then they may well be able to bridge short periods of low solar radiation and to thereby meet the annual heating and hot water demand for much of the year [9-10]. However, around half of the total annual heating requirement of a domestic building occurs during approximately two months over mid-winter when there is the least amount of available solar radiation [5]. In order to span this period and to support a comfortable indoor temperature, the solar heating system must either be supported by a secondary heating system using an imported energy source, or it must have the ability to store a sufficient quantity of energy which can be continually drawn upon during this period. The 
latter option, often referred to as seasonal energy storage, requires an optimal size and positioning of the solar thermal collectors and is designed to accumulate sufficient thermal energy in the form of sensible heat during the summer and early autumn, when solar radiation is most available but least required, so that all the heating and hot water requirements of the building occupants can be provided throughout the following winter. Such a system would have an annual solar fraction of $100 \%$, where the solar fraction is defined as the ratio of solar energy supplied to the heating energy demand of the building. Periods of winter sunshine will be exploited to supplement the stored mass as and when available.

Although there has already been a significant body of research work conducted into the seasonal storage of thermal energy using various mediums (for a technology overview see Swet [11] or Hadorn [5]), Life Cycle Assessment (LCA) studies have focused on relatively small solar hot water or heating systems for single family houses [12 - 15]. This focus of research reflects current technical practice; in central Europe there are very few functional examples where, having been in operation for several years, a 100\% solar fraction demand coverage (including acceptable reserve capacity) has been achieved whilst simultaneously operating under relatively normal demand dynamics. One example, however, is that of a single family house built in Switzerland in 1989 and for which the water-based seasonal thermal energy storage system is located in a subterranean cellar $[9,16]$. Although successful, the heat storage system comprises of two insulated vessels which is a design compromise due to above ground spatial restrictions. Within the storage vessel(s), the body of water does not heat up and cool down as one mass but, over time, it exhibits dynamic temperature stratification according to depth [17]. This means that the optimisation of the storage vessel's height to diameter not only improves the functional ability of the system to store heat but also helps to minimise the overall spatial requirement. Whilst having been proven as functionally successful, this technology has now been developed further to the extent that in 2005 a low energy building of eight apartments was constructed which integrated a single seasonal thermal energy storage vessel vertically into the centre of the building in order to provide $100 \%$ solar fraction coverage of the occupants' heating and hot water demand. This apartment building is also located in the central region of Switzerland and, according to Joika et al. [9], it is the first of its kind in Europe.

This form of heating technology appears to offer a very positive progression towards the fulfilment of the 2000W society criteria. However, this conclusion would be reached without having first understood the more specific impacts on the environment and sustainable development caused by the complete life-cycle of a system of this type and, based on the assessment of its life-cycle, whether it exhibits merits over alternative heating systems. This paper describes the methodology and results of research which concentrates on the energy demand, resource depletion and potential environmental and human health 
impacts associated with the complete life-cycle of the solar thermal system (STS) with seasonal energy storage incorporated into the apartment building desribed above. The work uses the LCA methodology as defined by the ISO [18]. Four different storage tank lifetimes (40, 50, 60 and 75 years) and three solar collector lifetimes (20,25 and 30 years) were used due to the high uncertainity surrounding these factors. The results are compared to those of five alternative heating systems technologies: an air-source heat-pump, a ground-source heat pump, a natural gas furnace, an oil furnace and a wood-pellet furnace. In Switzerland, these form the predominant systems used in this type of building and for which, in some regions, it is no longer permitted to install pure electric boilers ${ }^{1}$. Hybrid systems such as solar-wood pellet, solar-gas, solarheat pump etc. can also be used for supplying heating in these types of buildings and can be effective in reducing energy consumption. However, determining suitable dimensions and capacities for such systems according to solar radiation and load fluctuations meant that hybrid systems were considered outside the scope of this intial study, which aims to compare the STS sytem with the predominant heating system types. Following the results of the initial comparison presented in this paper, such an analysis would however form valuable follow-up research.

The present analysis is based on the current electricity supply mix and focuses on the overall environmental impacts rather than the operational energy and exergy efficiencies of the STS (which can be used for design improvement purposes). The findings present a complete evaluation of the life-cycle impacts of solar thermal systems with seasonal storage and illustrate their potential for reducing energy consumption and greenhouse gas emissions in current and future residential buildings.

\section{Systems characteristics and data collection}

The heating systems were modelled to the point of heat output to the heat distribution network within the building and the research therefore assumed that all of the heating technologies used in the comparison would employ the same distribution system. The apartment building itself was therefore not analysed in the assessment. The potential impacts are presented using the functional unit of $1 \mathrm{MJ}$ of heat energy output which allows comparisons between the heating systems to be made.

\subsection{The solar thermal system (STS)}

The apartment building is located in a lowland region of the Canton of Berne in Switzerland and at an elevation above sea level of approximately 550 meters. According to MeteoSchweiz [19], total annual

\footnotetext{
1 E-mail response from The Department for Construction, Transport and Environment, Specialist Department Energy, Canton Aargau, Switzerland 19.12.2008.
} 
sunshine accumulates to approximately 1,550 hours. Winter temperatures range from a daily average of around $-1^{\circ} \mathrm{C}$ to an average daily minimum of around $-5^{\circ} \mathrm{C}$ and average cloud cover ranges from a minimum of around $55 \%$ in July to $80 \%$ from November to February.

The STS was designed and built prior to construction of the apartment building which was originally intended to meet the Minergie-standard [6] for buildings in Switzerland. This requires an apartment building to have a heating energy demand $60 \%$ less than that of the conventional Swiss building standards [7]. However the building efficiency plans changed and on completion the apartment building achieved the higher standard of Minergie-P [20] which requires the fulfilment of various criteria, including only $30 \%$ energy demand and marginal additional construction costs in comparison to the conventional standards. For the purposes of the research it was assumed that the originally planned levels of energy demand are present.

As shown in Figure 1, the STS consists predominantly of two components: the seasonal thermal energy storage vessel and the solar collector field. The storage vessel is an insulated mild steel cylinder containing steel heat exchanger coils and three stainless steel boilers in which is heated the potable hot water. These boilers are placed at different levels within the storage vessel and only one is used at any time. The stored water cools from the bottom up and, once the water temperature drops below a certain threshold, the higher boiler is used to achieve the desired temperature. The flat plate solar collectors form the whole south-facing side of the roof and are specifically designed to function as the roofing cover. Only the glass and rubber seals are externally exposed which allows the structural elements to be constructed of timber.

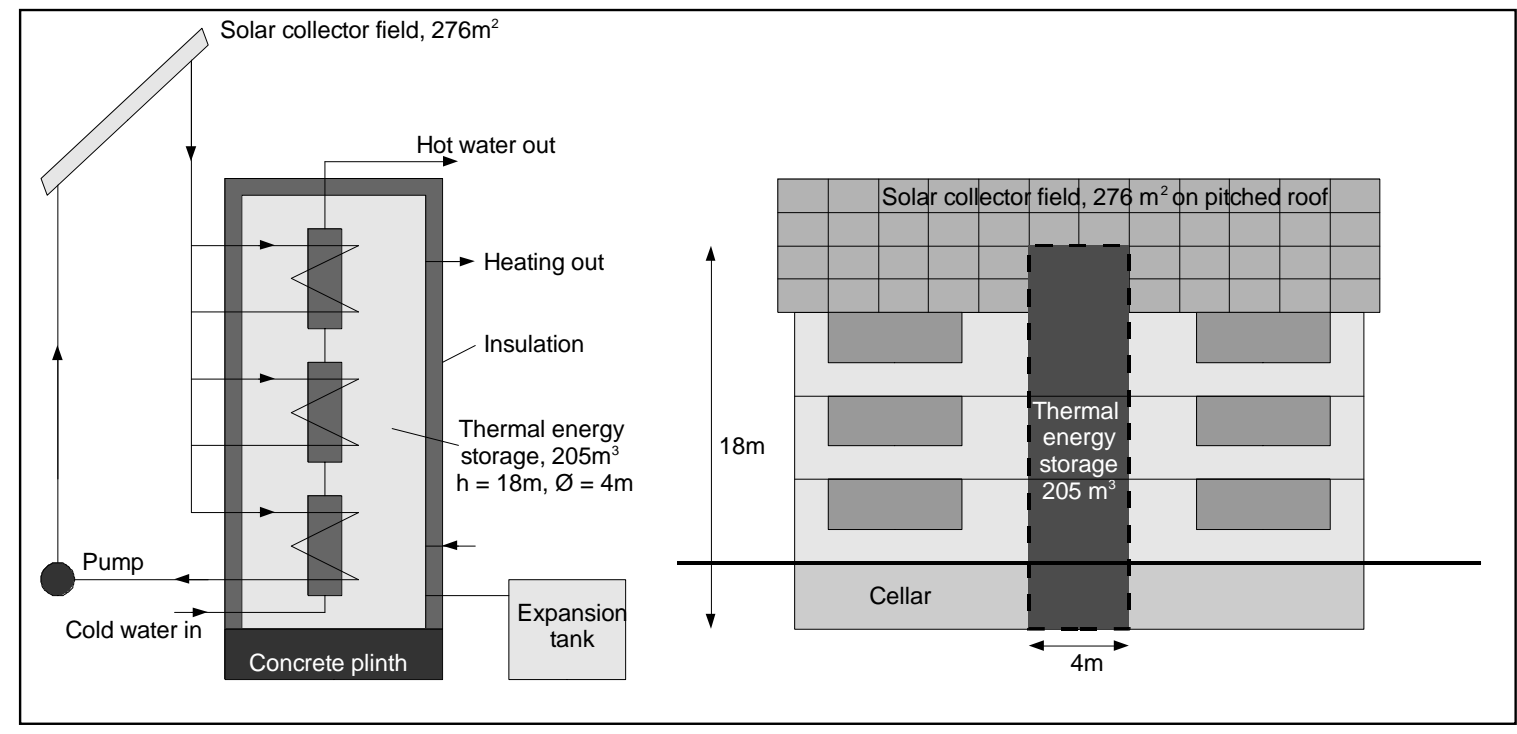

Figure 1. The main components and operational flows of the solar thermal system (STS). Also the approximate location and size relative to the apartment building. 
A fluid mixture of water and anti-freeze is heated in the solar collectors and circulated to the seasonal storage vessel where it passes through heat exchanger coils. The thermal energy is transferred to the stored mass of water within the vessel and therefore also to the three warm water boilers. The heated water mass within the store can then be circulated throughout the heating network of the building.

It was necessary to compile a life cycle inventory $(\mathrm{LCl})$ of the significant inputs and outputs associated with the life-cycle of the seasonal storage vessel, the solar collectors and also the infrastructure necessary for it to function. For most of the individual processes and commonly found components of the complete system the research used existing data from an established LCI database [21].

The expected operational lifetime of the storage vessel is very much unproven but it should, however, be significantly greater than the lifetime of solar collectors which are relatively better understood. According to Konttinen and Lund [22] and Köhl et al. [23], a flat plate solar collector should be able to achieve a service lifetime of 25 years. Due to this general uncertainty, the whole STS was assessed using four different storage system lifetime scenarios (40,50 60 and 75 years) in conjunction with three collector lifetimes (20, 25 and 30 years). The total energy output was calculated for the five lifetime scenarios and used to express the potential impacts of the entire system. It was assumed that maintenance requirements consist of the replacement of the solar collector field at 20, 25 or 30 year time intervals; the impacts of other maintenance are considered insignificant. Furthermore, at the end of their lifetime the solar collectors are replaced with the same type of solar collectors with identical efficiency.

\subsection{The heating systems used in the comparison}

Heating systems to be used in the comparison were chosen on the basis of existing and progressive technologies currently used in Swiss apartment buildings of this size and all inventory datasets for these were taken from the ecoinvent database [21]. The comparison used a total of five alternative heating systems, these included: an air-source heat-pump; a ground-source heat-pump; a natural gas fuelled furnace; a light fuel oil fuelled furnace; and a wood pellet fuelled furnace. These systems were sufficiently proportioned so that the times of peak demand can be met and in conjunction with a hot water storage vessel of sufficient volume in order to regulate the operating frequency of the heat source. All except the gas boiler could be scaled to $30 \mathrm{~kW}$, the gas boiler specified as being less than $100 \mathrm{~kW}$ in the ecoinvent database. Of most significance to the heat-pumps, the Swiss electricity supply mix is representative of the year 2005, including electricity imports. On a fuel basis it consists of around $50 \%$ nuclear, $36 \%$ hydro, $10 \%$ fossil and $4 \%$ non-hydro renewable sources [21]. 
Table 1 The heating systems used in the comparative LCA

\begin{tabular}{|c|c|c|}
\hline Heating system type & $\begin{array}{c}\text { System and } \\
\text { scenario } \\
\text { abbreviation }\end{array}$ & Description \\
\hline \multirow{6}{*}{$\begin{array}{c}\text { Solar Thermal System } \\
\text { (STS) } \\
205 \mathrm{~m}^{3} \text { seasonal } \\
\text { storage, } \\
276 \mathrm{~m}^{2} \text { solar collector } \\
\text { field }\end{array}$} & 40 yrs $2 \mathrm{CF}$ & 40 yr system lifetime requiring 2 collector fields \\
\hline & $\begin{array}{l}40 \text { yrs } 2 C F \\
\text { (SA) }\end{array}$ & $\begin{array}{l}\text { Sensitivity analysis (SA) conducted on electricity use } \\
\text { inventoried for manufacture and disposal (as described in } \\
\text { Section 2.3) }\end{array}$ \\
\hline & 50 yrs $2 \mathrm{CF}$ & 50 yr system lifetime requiring 2 collector fields \\
\hline & 60 yrs $2 C F$ & 60 yr system lifetime requiring 2 collector fields \\
\hline & 60 yrs $3 C F$ & 60 yr system lifetime requiring 3 collector fields \\
\hline & 75 yrs $3 C F$ & 75 yr system lifetime requiring 3 collector fields \\
\hline \multirow[t]{2}{*}{ Heat pump } & Air-source & $\begin{array}{l}40 \mathrm{yr} \text { system lifetime requiring } 2 \text { heat pumps. SPF } 2.8 \text {. } \\
30 \mathrm{~kW} \text {, air-to-water, } 2005 \mathrm{CH} \text { electricity supply mix. }\end{array}$ \\
\hline & $\begin{array}{l}\text { Ground- } \\
\text { source }\end{array}$ & $\begin{array}{l}40 \text { yr system lifetime requiring } 2 \text { heat pumps. SPF } 3.9 . \\
30 \mathrm{~kW} \text {, water-to-water, } 2005 \mathrm{CH} \text { electricity supply mix. }\end{array}$ \\
\hline \multirow[t]{2}{*}{ Fossil fuel } & Gas & $\begin{array}{l}40 \text { yr system lifetime requiring } 2 \text { gas furnaces. } \\
<100 \mathrm{~kW} \text {, condensing, modulating. Efficiency } 87 \%\end{array}$ \\
\hline & Oil & $\begin{array}{l}40 \mathrm{yr} \text { system lifetime requiring } 2 \text { oil furnaces. } \\
30 \mathrm{~kW} \text {, condensing, non-modulating. Efficiency } 85 \%\end{array}$ \\
\hline Biomass & Wood pellets & $\begin{array}{l}40 \mathrm{yr} \text { system lifetime requiring } 2 \text { furnaces. } \\
30 \mathrm{~kW}, \mathrm{CH} \text { pellets, mixed wood. Efficiency } 82 \%\end{array}$ \\
\hline
\end{tabular}

Results for the heating systems used in the comparison are shown in terms of lifetimes of 40 years only. The same lifetimes to those of the STS were also modelled for these technologies but the results displayed very little variation. This is because of the very small contributions from the heating system infrastructures in comparison with the STS.

\subsection{Sensitivity analysis (SA)}

The use of lifetime scenarios represents the most significant aspect of the sensitivity analysis and is therefore intended to offer interpretation possibilities. Uncertainty concerning electricity consumption is due to the difficulty of obtaining data for individual processes and of manufacturers understandably not having records of this data for single products. By this is meant, for example, electricity consumed in fabricating the concaved ends of the thermal storage vessel as well as the installation and the eventual dismantling of the complete STS. It was decided that a simple and effective sensitivity analysis this input to the inventory would be to double the initial values. This is applied only to the first lifetime scenario in the impact assessment, denoted as "(SA)". The parameters of the sensitivity analysis therefore encompass both infrastructural and operational uncertainties, and the influences of these are given in the impact assessment. 


\subsection{Energy supply and demand of the solar thermal system}

The calculation of the heat output of the STS was based on the building's requirement of $11 \mathrm{~kW}$ at an outdoor temperature of $-8^{\circ} \mathrm{C}$, a figure provided by the thermal storage vessel manufacturer (Jenni [24]). By using a base outdoor temperature of $12^{\circ} \mathrm{C}$ (above which the heating will not be used) it was possible to calculate the heating demand per degree of temperature difference between the inside and the outside. Knowing this value allowed regional average degree day data [25] to be applied in order to determine the total heating energy demand that the STS must be able to satisfy and was calculated to be $172,070 \mathrm{MJ} / \mathrm{year}$. The energy required for potable hot water supplied to taps is $75 \mathrm{MJ} / \mathrm{m}^{2} / y e a r$ [7]. Having a heated floor area of $1,282 \mathrm{~m}^{2}$ the annual demand is therefore $96,150 \mathrm{MJ} / \mathrm{year}$. The total annual thermal energy requirement is then the sum of these results and equal to $268,220 \mathrm{MJ} / \mathrm{year}$. Assuming that the energy demand for potable hot water is constant throughout the year, the overall average heat demand on the system at an outdoor temperature of $-8^{\circ} \mathrm{C}$ is therefore $14 \mathrm{~kW}$.

In order to calculate the operational energy demand (parasitic demand) of the STS it was assumed that when the sun shines that the circulation pump will be operating. Regional data [19] combined with a pump of $400 \mathrm{~W}$ gave a parasitic energy demand of 2,236 MJ/year. Combining the annual heating energy ouput values with the lifetime scenarios allowed the total energy outputs to be calculated. The parasitic energy demand is the same for $1 \mathrm{MJ}$ of output regardless of the lifetime scenario.

\subsection{Inventory data collection}

Quantitative data was collected from the manufacturers of the STS components and from standardised values used in the compilation of inventories. Many of the materials and processes common to the STS have been heavily researched and inventoried using a consistent methodology within the ecoinvent database [26]. Where significant unit processes do not exist, these were either modelled during the study or approximated depending on their relevance to the results. The cut-off criterion for the various metallic materials of the storage vessel used a minimum mass factor of $1 \%$ of the total whilst the material inventory of the collectors was supplied by the manufacturers and combined with generic process data. For all other material inputs such as paint, insulation and those used in welding, a cut-off point of $0.2 \%$ was achieved. At the end of a material's sevice life within the system it will either be disposed of or recycled. Even if recycled to $100 \%$, the initial acquisition of the material may consist of a mix of primary and secondary (recycled) material if not infact being purely from primary sources. An allocation of resource burdens is therefore applicable even for the case of $100 \%$ recycling at end-of-life. In the case of steel for example, production of $1 \mathrm{~kg}$ is modelled using the inputs of $630 \mathrm{~g}$ primary and $370 \mathrm{~g}$ secondary. At the end-of-life it is assumed to be 
fully recycled. In this paper, the allocation of burdens to the use of materials is therefore done using the recycled content approach. Here, the recycling of a material is allocated to the life cycle of the proceeding product using it - in the form of secondary material, following the approach used in the ecoinvent methodology [26].

Generic data was also used to account for capital goods and process emissions. Energy inputs were both from generic and approximated sources. The influences of approximated data for significant inputs or processes were subjected to sensitivity analysis whereby the data were changed and the impacts on the results were observed. Tables 2 and 3 show the quantities for each dataset entered into the SimaPro impact assessment software [27]. The software uses the datasets to generate an extensive list quantifying the individual emissions and resources (elementary flows) attributable to the overall system; these are the inventory results. The software is then used to apply the selected impact assessment methodologies in order to evaluate the potential impacts according to the indicators selected as being relevant to the goal of the Life Cycle Assessment (see Section 3). 24 materials/processes were identified for the construction of the storage vessel and 28 for the solar collectors. Processes include the use of capital goods such as the metal working factory for which a fraction is attributed per kg of product. Transport data uses generic values for heavy industry products such as steel and concrete, and case specific data for the transport of other materials including transport of the end products to the building construction site.

Table 2. Life cycle inventory of the storage vessel and infrastructure.

\begin{tabular}{|c|c|c|c|c|c|}
\hline Material / process & Amount & Unit & Material / process & Amount & Unit \\
\hline Steel, low alloyed, RER & 18500 & $\mathrm{~kg}$ & $\begin{array}{l}\text { Tube insulation, } \\
\text { elastomere, at plant, DE }\end{array}$ & 100 & $\mathrm{~kg}$ \\
\hline Sheet rolling, steel, RER & 16500 & $\mathrm{~kg}$ & Pump, 40W, at plant, $\mathrm{CH}$ & 8 & pieces \\
\hline Pipe-drawing, steel, RER & 2000 & $\mathrm{~kg}$ & $\begin{array}{l}\text { Concrete, normal, at } \\
\text { plant, } \mathrm{CH}\end{array}$ & 10 & $\mathrm{~m}^{3}$ \\
\hline $\begin{array}{l}\text { Chromium steel } 18 / 8 \text {, at plant, } \\
\text { RER }\end{array}$ & 250 & $\mathrm{~kg}$ & $\begin{array}{l}\text { Reinforcing steel, at } \\
\text { plant, RER }\end{array}$ & 1000 & $\mathrm{~kg}$ \\
\hline $\begin{array}{l}\text { Sheet rolling, chromium steel, } \\
\text { RER }\end{array}$ & 250 & $\mathrm{~kg}$ & Transport, freight, rail, $\mathrm{CH}$ & 12800 & $\mathrm{tkm}$ \\
\hline Welding, gas, steel, RER & 400 & $m$ & $\begin{array}{l}\text { Transport, lorry }>28 t \text {, fleet } \\
\text { average, } \mathrm{CH}\end{array}$ & 2300 & $\mathrm{tkm}$ \\
\hline Metal working factory, RER & $8.59 \mathrm{E}-6$ & parts & $\begin{array}{l}\text { Transport, lorry } 20-28 t, \\
\text { fleet average, } \mathrm{CH}\end{array}$ & 125 & $\mathrm{tkm}$ \\
\hline $\begin{array}{l}\text { Metal working machine, } \\
\text { unspecified, at plant,RER }\end{array}$ & 0.741 & $\mathrm{~kg}$ & Tap water, at user, $\mathrm{CH}$ & 206000 & $\mathrm{~kg}$ \\
\hline $\begin{array}{l}\text { Alkyd paint, } 60 \% \text { in solvent, at } \\
\text { plant, RER }\end{array}$ & 50 & $\mathrm{~kg}$ & $\begin{array}{l}\text { Electricity, low voltage, at } \\
\text { grid, } \mathrm{CH}\end{array}$ & 3600 & kWh \\
\hline Glass wool matt, at plant, RER & 750 & $\mathrm{~kg}$ & $\begin{array}{l}\text { Waste heat - high } \\
\text { population density }\end{array}$ & 12960 & MJ \\
\hline $\begin{array}{l}\text { Aluminium (foil), production } \\
\text { mix, at plant, RER }\end{array}$ & 13.5 & $\mathrm{~kg}$ & $\begin{array}{l}\text { Disposal, mineral wool to } \\
\text { sorting plant, } \mathrm{CH}\end{array}$ & 750 & $\mathrm{~kg}$ \\
\hline $\begin{array}{l}\text { Laminating, foil, with acrylic } \\
\text { binder, RER }\end{array}$ & 250 & $\mathrm{~m} 2$ & $\begin{array}{l}\text { Disposal, reinforced } \\
\text { concrete to sorting, } \mathrm{CH}\end{array}$ & 2300 & $\mathrm{~kg}$ \\
\hline
\end{tabular}


Table 3. Life cycle inventory for $1 \mathrm{~m}^{2}$ of solar flat plate collector.

\begin{tabular}{|c|c|c|c|c|c|}
\hline Material / process & Amount & Unit & Material / process & Amount & Unit \\
\hline $\begin{array}{l}\text { Copper, at regional storage, } \\
\text { RER }\end{array}$ & 3.88 & $\mathrm{~kg}$ & $\begin{array}{l}\text { Corrugated board, single } \\
\text { wall, at plant, RER }\end{array}$ & 0.24 & $\mathrm{~kg}$ \\
\hline $\begin{array}{l}\text { Titanium dioxide, production } \\
\text { mix, at plant, RER }\end{array}$ & 1.67E-3 & $\mathrm{kg}$ & $\begin{array}{l}\text { Transport, transoceanic } \\
\text { freight ship, OCE }\end{array}$ & 95.5 & tkm \\
\hline Silica sand, at plant, DE & $9.0 \mathrm{E}-4$ & $\mathrm{~kg}$ & $\begin{array}{l}\text { Transport, freight, rail, } \\
\text { RER }\end{array}$ & 16.82 & tkm \\
\hline Metal coating plant, RER & 3.33E-7 & Parts & $\begin{array}{l}\text { Transport, lorry }>32 t \text {, } \\
\text { EURO5, RER }\end{array}$ & 11.7 & tkm \\
\hline $\begin{array}{l}\text { Brazing solder, cadmium free, } \\
\text { at plant, RER }\end{array}$ & $3.68 \mathrm{E}-3$ & $\mathrm{~kg}$ & $\begin{array}{l}\text { Transport, lorry 16-32t, } \\
\text { EURO5, RER }\end{array}$ & 1.4 & tkm \\
\hline $\begin{array}{l}\text { Soft solder, Sn97Cu3, at plant, } \\
\text { RER }\end{array}$ & $5.88 \mathrm{E}-2$ & $\mathrm{~kg}$ & $\begin{array}{l}\text { Propylene glycol, liquid, } \\
\text { at plant, RER }\end{array}$ & 1.03 & $\mathrm{~kg}$ \\
\hline Rock wool, at plant, $\mathrm{CH}$ & 1.28 & $\mathrm{~kg}$ & Tap water, at user, RER & 9.4 & $\mathrm{~kg}$ \\
\hline $\begin{array}{l}\text { Plywood, external quality, at } \\
\text { plant, RER }\end{array}$ & 0.01 & $\mathrm{~m}^{3}$ & $\begin{array}{l}\text { Electricity,low voltage, at } \\
\text { grid, DE }\end{array}$ & 2.03 & $\mathrm{kWh}$ \\
\hline $\begin{array}{l}\text { Sawn timber, hardwood, } \\
u=10 \% \text {, at plant, RER }\end{array}$ & $1.05 \mathrm{E}-2$ & $\mathrm{~m}^{3}$ & $\begin{array}{l}\text { Waste heat - high } \\
\text { population density }\end{array}$ & 7.31 & MJ \\
\hline $\begin{array}{l}\text { Aluminium, production mix, at } \\
\text { plant, RER }\end{array}$ & 0.324 & $\mathrm{~kg}$ & $\begin{array}{l}\text { Disposal, glass sheet, to } \\
\text { sorting plant, } \mathrm{CH}\end{array}$ & 9.75 & $\mathrm{~kg}$ \\
\hline Synthetic rubber, at plant, RER & 0.413 & $\mathrm{~kg}$ & $\begin{array}{l}\text { Disposal, mineral wool, to } \\
\text { sorting plant, DE }\end{array}$ & 1.28 & $\mathrm{~kg}$ \\
\hline $\begin{array}{l}\text { Solar glass, low iron, at } \\
\text { regional storage, RER }\end{array}$ & 9.75 & $\mathrm{~kg}$ & $\begin{array}{l}\text { Disposal, cardboard, to } \\
\text { incineration, } \mathrm{CH}\end{array}$ & 0.24 & $\mathrm{~kg}$ \\
\hline $\begin{array}{l}\text { Anti-reflex coating, etching, } \\
\text { solar glass, RER }\end{array}$ & 1 & $m^{2}$ & $\begin{array}{l}\text { Disposal, rubber, to } \\
\text { incineration, } \mathrm{CH}\end{array}$ & 0.413 & $\mathrm{~kg}$ \\
\hline Solar collector factory, RER & $2.0 \mathrm{E}-7$ & Parts & $\begin{array}{l}\text { Treatment, heat carrier } \\
\text { liquid, } 40 \% \mathrm{C} 3 \mathrm{H} 8 \mathrm{O} 2 \text {, to } \\
\text { wastewater treatment, } \mathrm{CH}\end{array}$ & 0.00239 & $\mathrm{~m}^{3}$ \\
\hline
\end{tabular}

\section{$3 \quad$ Life Cycle Assessment Results}

\subsection{Impact assessment methodology}

The six heating technologies were assessed on the basis of four potential-damage categories relating to either the environment or to human health, as shown in Table 4. The inventory results contributing to indicators and to the damage categories have been weighted but not normalized, this being an optional additional step which was not conducted.

The consumption of natural resources was quantified in terms of primary energy and non-combustable mineral (abiotic) resources. These were chosen in order to determine, on a comparative basis, the comparatively large infrastructure requirement of the STS for abiotic resources and, on the other hand, its small demand for operational energy use from purchased sources. The emission of greenhouse gases (GHG) is a vital aspect of any assessment in order to understand the potential contributions to climate change and conventionally forms the main argumental basis for the development of solar thermal heating systems. It is therefore important to understand the GHG emissions from the complete life-cycle and not just 
the operational lifetime of the heating system. Further potential damages to the environment occur in the measurable form of reductions in biodiversity due to land use and from pollutants emitted to the air, the ground or into water. The indicator results contributing to this category are weighted but not normalised.

The potential direct and indirect impacts to the health of the global population is assessed using the Dissability Adjusted Life Year (DALY) which combines premature mortality and years of life lost due to the suffering of disabilities $[28,31]$. Again, the contributing indicator results are weighted but not normalised.

Table 4. Selected life cycle impact assessment methodologies employed in the research.

\begin{tabular}{|c|c|c|c|}
\hline $\begin{array}{l}\text { Damage } \\
\text { Category }\end{array}$ & Impact Indicator & Unit & Methodology \\
\hline \multirow{2}{*}{$\begin{array}{l}\text { Consumption of } \\
\text { resources }\end{array}$} & Primary energy use & $\mathrm{MJ} / \mathrm{MJ}$ & Cumulative Energy Demand [28] \\
\hline & Abiotic resources & $\mathrm{kg}(\mathrm{Sb}$ eq. $) / \mathrm{MJ}$ & CML 2001 - Abiotic resources [29] \\
\hline Climate Change & GHG emissions & $\mathrm{kg}\left(\mathrm{CO}_{2}\right.$ eq. $) / \mathrm{MJ}$ & IPCC $2007[28,30]$ \\
\hline \multirow{3}{*}{$\begin{array}{l}\text { Ecosystem } \\
\text { quality }^{\mathrm{a}}\end{array}$} & Land use & \multirow{3}{*}{$\mathrm{PDF}^{*} \mathrm{~m}^{2 *} \mathrm{a} / \mathrm{MJ}$} & \multirow{3}{*}{ 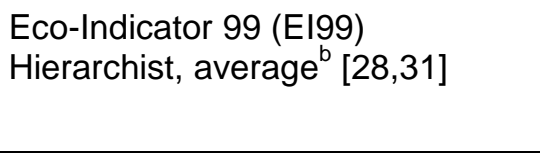 } \\
\hline & Ecotoxicity & & \\
\hline & Acidification \& Eutrophication & & \\
\hline \multirow{6}{*}{ Human health $^{c}$} & Carcinogens & \multirow{6}{*}{$\mathrm{DALY} / \mathrm{MJ}$} & \multirow{6}{*}{$\begin{array}{l}\text { Eco-Indicator } 99 \text { (EI99) } \\
\text { Hierarchist, average }[28,31]\end{array}$} \\
\hline & Respiratory organics & & \\
\hline & Respiratory inorganics & & \\
\hline & Climate change & & \\
\hline & Radiation & & \\
\hline & Ozone layer depletion & & \\
\hline
\end{tabular}

${ }^{a}$ Measured in terms of a Potentially Dissappeared Fraction of species (PDF)

b "Hierarchist; Average" refers to the treatment of uncertainties and the weighting values applied.

${ }^{c}$ Measured in Disability Adjusted Life Years (DALY)

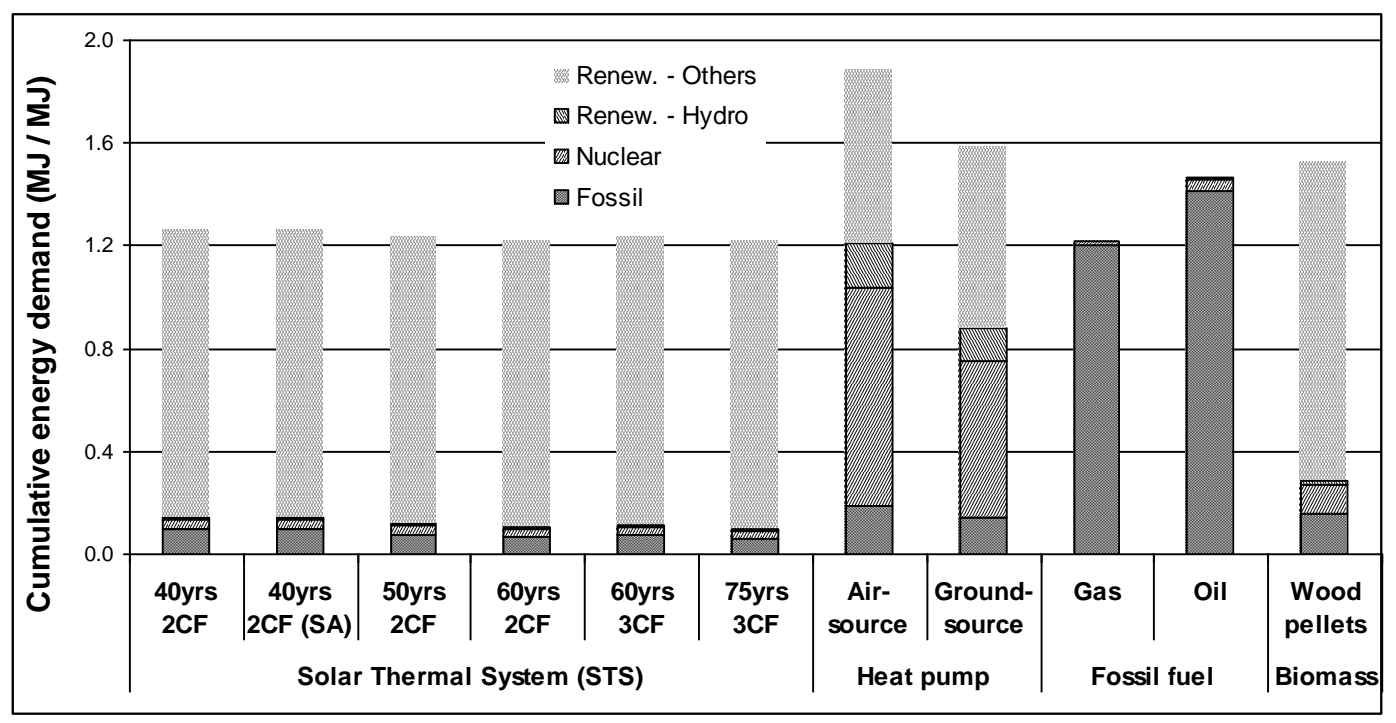

Figure 2. Cumulative energy demand (CED) of each system and contributing primary energy forms. 
This indicator is a direct quantification of primary energy resources allocated to each MJ of heat output and in this way differs from the other impact indicators which determine values either in terms of equivalency to a particular substance or through characterisational weighting in order to form a tangible impact. It is known as the cumulative energy demand (CED) and can be defined as the total amount of primary energy used over the complete life-cycle to deliver $1 \mathrm{MJ}$ of heating energy. Primiary energy sources include fossil fuels, nuclear, hydropower as well as solar thermal, geothermal, thermal energy of ambient air and biomass). Figure 2 also highlights the quantities of primary energy either requiring purchase from a provider or freely absorbed from the environment (solar radiation and thermal energy extracted from outdoor air and from the ground). On this later basis the STS shows a demand of between 7 and $16 \%$ that of the other systems.

As would be expected, the CED of all heating systems and scenarios are dominated by the primary energy used in the operation rather than the other life-cycle stages. For the STS, fossil fuels consumed during the processing of raw materials and the manufacturing of components represents around $10 \%$ of the overall CED. The length of the lifetime is shown to make little overall difference between the five STS scenarios as well as on the sensitivity analysis conducted on primary energy used for manufacture, installation and disposal. The results show the small contribution from other non-operation life-cycle aspects on a MJ/MJ basis. The overall demands of the STS scenarios are similar to that of the gas fossil heating system, the major difference being that for the STS approximately $85 \%$ is direct solar radiation. Refering to the shortest lifetime scenario, the STS consumes around $12 \%$ of the purchased primary energy of the air-source heat pump and around $16 \%$ that of the ground-source heat pump. The Swiss electricity supply mix and the large contribution from nuclear are reflected in the primary energy use of the heat-pumps. The ground-source heat-pump operates with a higher efficiency than the air-source heat-pump by gaining more thermal energy from the borehole. Although the primary energy demand for the wood pellet system is mostly derived from the renewable biomass heating fuel, it has a higher demand for electricity in order to operate than has the STS and also consumes marginally more fossil fuels during harvesting of the timber and production and transport of the pellets than is used for the STS during manufacture and disposal. 


\section{3}

\section{Abiotic resource depletion}

This indicator quantifies the total amount of non-combustable mineral resources used over the life cycle of each heating system with relevance to $1 \mathrm{MJ}$ of useful heat. It is based on the impact assessment methodology ' $C M L 2001$ ' but is modified to model the use of non-combustable mineral (abiotic) resources only. The measurement of single metals is based on the scarcity of their ores and expressed with reference to an equivalent use of the metal antimony $(\mathrm{Sb})$.

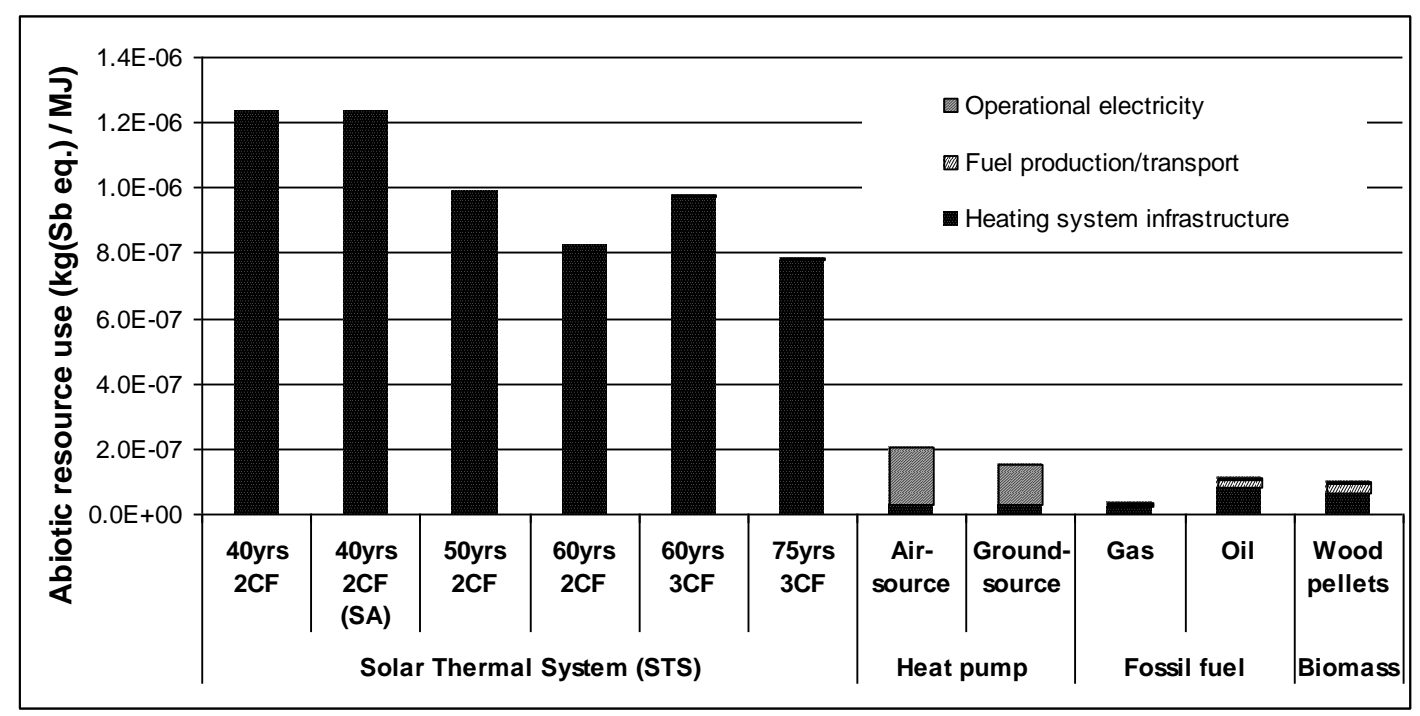

Figure 3. Life-cycle requirement of abiotic (mineral non-energy) resources by each system.

Analysis of the different heating systems on the basis of mined resources in Figure 3 shows that the quantities determined for each system are very much due to just one aspect of the life cycle. Even considering the proportions of secondary (recycled) material used in individual metals ( $37 \%$ for steels, $44 \%$ for copper) the STS has a very large requirement for abiotic resources, although once installed there are no further significant demands. With reference to the 40yrs $2 \mathrm{CF}$ scenario, contributions to this impact indicator originate most significantly from molybdenum (around 60\%) in the steel alloy of the storage vessel, and the copper (almost 30\%) used in the collectors. The overall contribution from the infrastructure of the storage vessel is around $70 \%$ and from the collectors around $30 \%$. When 3 collector fields become necessary then this relationship changes to around $60 \%$ and $40 \%$ respectively and the increased demand from the collectors can be seen in the difference between the two 60 year lifetime scenarios. The compared heating systems show far lower mineral resource demands. For the heat pumps the demand is almost all due to the electricity generation infrastructure required for the operational lifetimes. Of this, the most significant resource is copper which accounts for $65 \%$ of the total resource use in equivalence to antimony (Sb). 


\subsection{Greenhouse gas (GHG) emissions}

This indicator measures the total quantity of greenhouse gases (GHG) released into the atmosphere from the complete life cycle of the heating systems. Using the global warming potential (GWP) over 100 years of one $\mathrm{kg}$ of carbon dioxide $\left(\mathrm{CO}_{2}\right)$ as the reference impact and equal to a GWP of 1, other GHG's are quantified according to their characteristic equivalence to $\mathrm{CO}_{2}$.

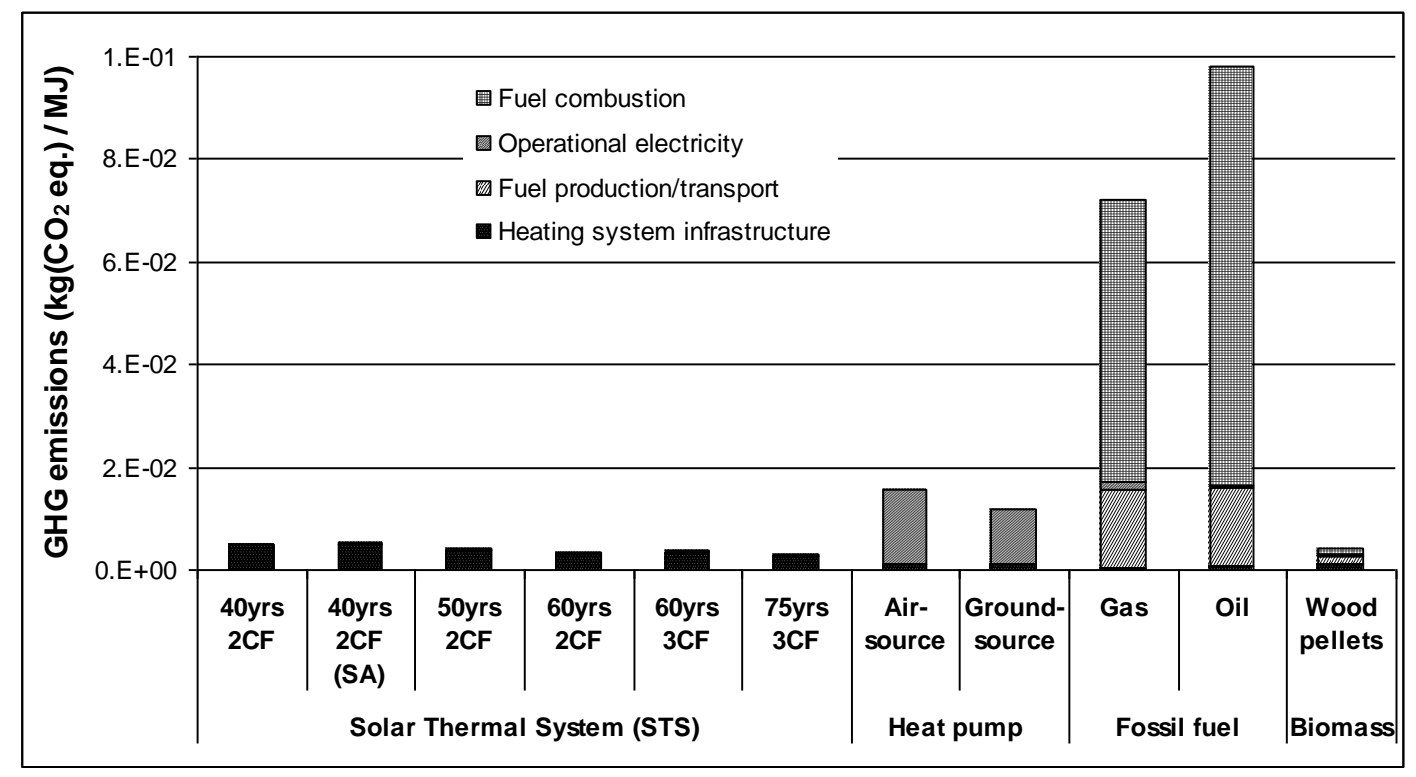

Figure 4. Life-cycle greenhouse gas (GHG) emissions of each heating system.

Figure 4 also shows that each heating system is dominated by the emissions from one aspect of the life cycle and when the complete life-cycle is considered then it can be seen that all of the heating systems have indirect emissions of GHG's associated with them. For the STS these emissions are mainly caused by fossil fuel-fired power plants providing electricity to the industrial processes of the steel industry and to manufacture of the collectors. The indirect GHG emissions from operation of the heat pumps originate predominantly from the energy chains of imported electricity rather than from Swiss inland production. $78 \%$ of the GHG emissions from the electricity used are due to the production from coal and lignite-fired power plants in Germany and coal-fired plants in France. These imports cause the total emissions associated with the heat pumps to be noticeably higher than any STS lifetime scenario. For the wood pellet system, the research did not include biogenic sources of $\mathrm{CO}_{2}$ in order to account for the uptake during tree growth. The overall GHG emissions from the wood pellet system are seen to be very similar to the STS scenarios. 


\section{5}

\section{Ecosystem quality}

The potential damage to ecosystem quality is determined by accumulating the results of the three impact indicators; land use, ecotoxicity and acidification \& eutrophication. The indicators measure the impact on flora and fauna caused by either a loss of biodiversity (land use), pollution (ecotoxicity) or the alteration of natural acidity and nutrient levels (acidification and eutrophication). Impacts are quantified in terms of a "potentially disappeared fraction" (PDF) of species attributable to $1 \mathrm{MJ}$ heat output. The PDF of species is expressed according to land area and time, and is modeled using the Eco-Indicator 99 (EI99) impact assessment methodology and a hierarchist treatment of uncertainties and average value weighting [24].

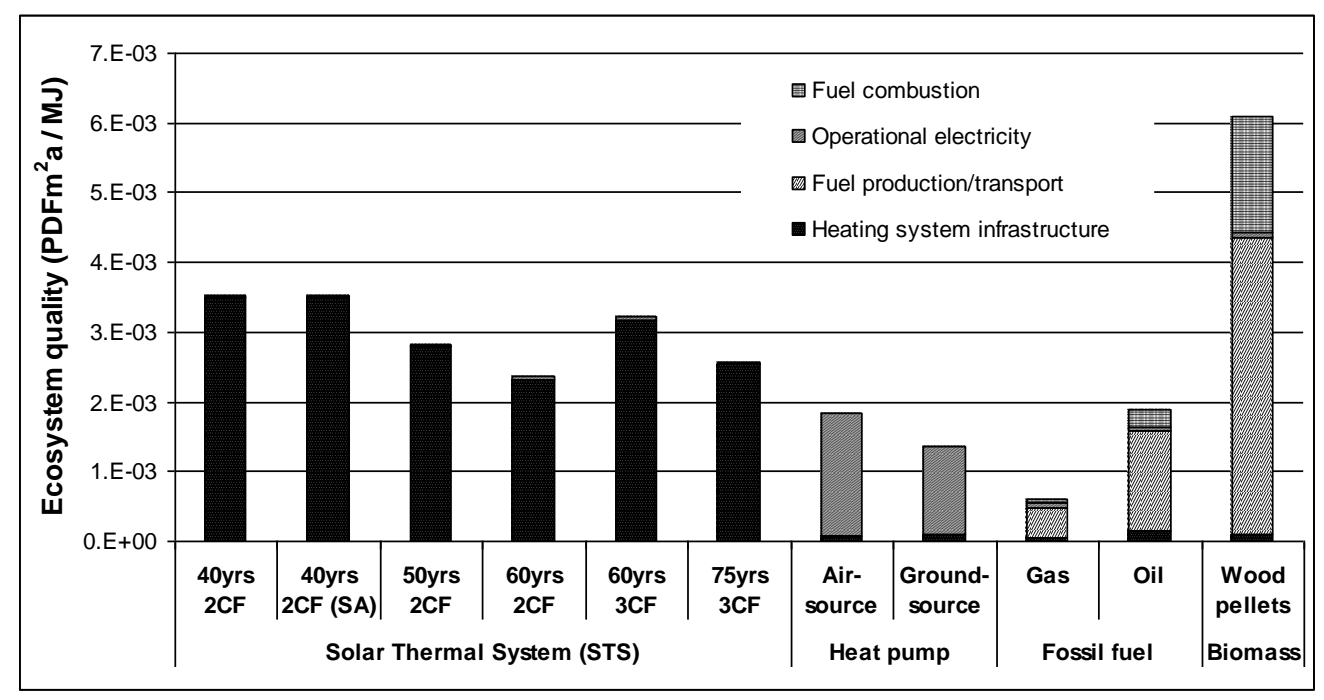

Figure 5. Potential impacts on ecosystem quality due to the life-cycle of each heating system.

For the STS, emissions from the mining and processing of primary copper used in the collectors accounts for more than one third of the overall impacts. Another significant contribution is the impact of land use for the production of timber which is the primary casing material of the collectors. The heat pumps also show dominance by just one life cycle stage. This is due to ecotoxic heavy metal emissions to the ground caused by electricity pilons made of treated timber as well as emissions from copper production used in the electricity distribution network. For the wood pellet system, land use change impacts associated with fuel production account for almost all impacts at this life cycle stage. The individual differences between the STS scenarios are however more pronounced, and the long-term advantages of prolonged operation leading to lower impacts per MJ heating can be appreciated. 
Table 5. Contribution analysis of indicators accumulated under the category Ecosystem Health.

\begin{tabular}{|l|l|c|c|c|}
\hline \multicolumn{2}{|c|}{ Heating system } & $\begin{array}{c}\text { Land use } \\
(\%)\end{array}$ & $\begin{array}{c}\text { Ecotoxicity } \\
(\%)\end{array}$ & $\begin{array}{c}\text { Acidification \& } \\
\text { Eutrophication } \\
(\%)\end{array}$ \\
\hline \multirow{4}{*}{ Solar } & 40yrs 2CF & 36.6 & 57.7 & 5.7 \\
\cline { 2 - 5 } & 40yrs 2CF (SA) & 36.8 & 57.7 & 5.5 \\
\cline { 2 - 5 } & 50yrs 2CF & 36.6 & 57.7 & 5.7 \\
\cline { 2 - 5 } & 60yrs 2CF & 36.5 & 57.8 & 5.7 \\
\cline { 2 - 5 } & 60yrs 3CF & 38.5 & 56.2 & 6.7 \\
\cline { 2 - 5 } & 75yrs 3CF & 38.4 & 56.2 & 6.8 \\
\hline \multirow{3}{*}{ pump } & Air-source & 10.3 & 79.8 & 9.9 \\
\cline { 2 - 5 } & Ground-source & 10.4 & 78.8 & 10.8 \\
\hline \multirow{3}{*}{ Fossil } & Gas & 36.6 & 22.5 & 40.9 \\
\cline { 2 - 5 } & Oil & 35.5 & 35.6 & 28.9 \\
\hline Biomass & Pellets & 63.4 & 24.4 & 12.2 \\
\hline
\end{tabular}

\subsection{Human health}

In a similar manner to the damage category Ecosystem Health, the potential damage to Human Health is determined by adding together the results of six impact indicators which are all quantified in terms of Dissability Adjusted Life Years (DALY) resulting from 1MJ heat output from each system's life cycle. The contributing impact indicators (see also Table 4) measure the potential health effects of carcinogens, respiratory organics, respiratory inorganics, climate change, radiation and ozone layer depletion [29,31].

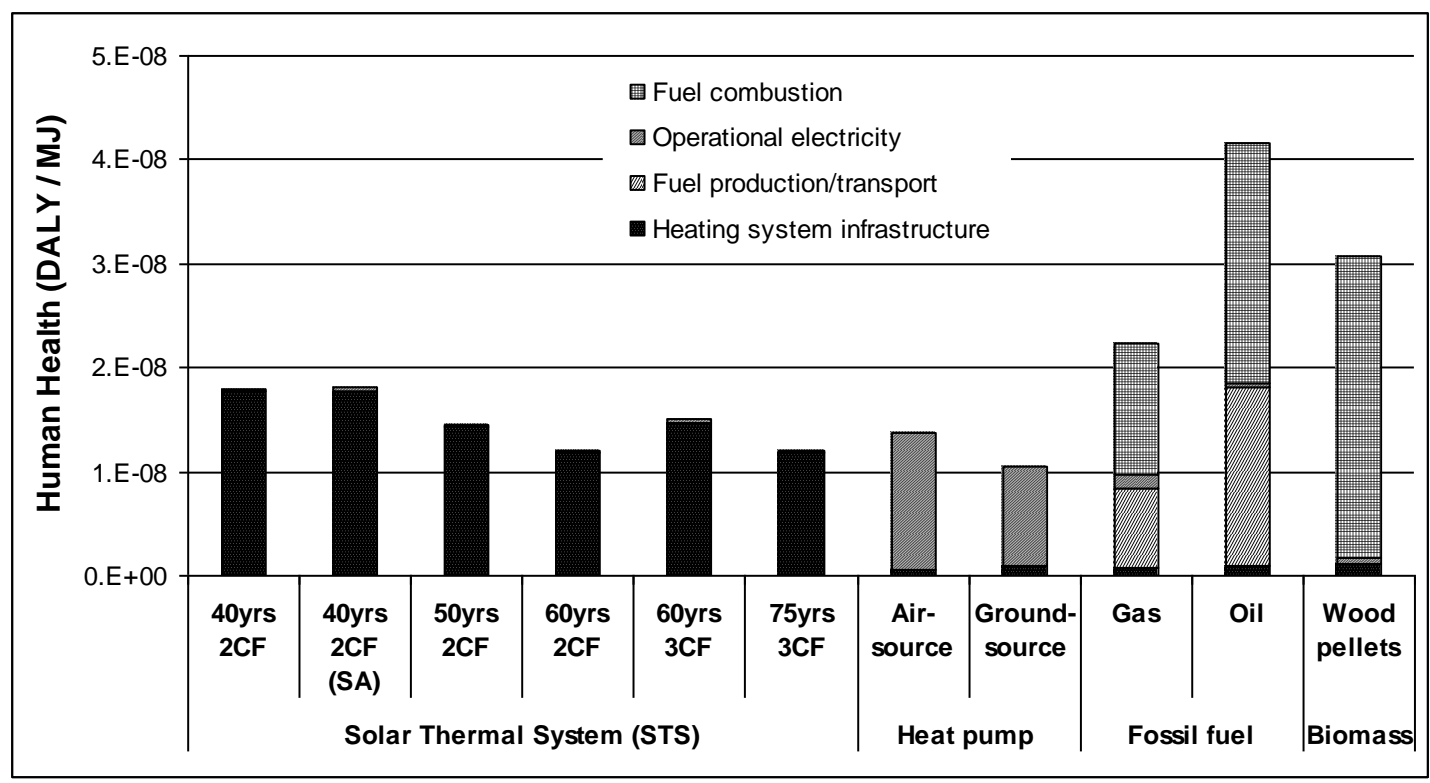

Figure 6. Potential impacts on human health due to the life-cycle of each heating system. 
The potential impacts due to toxic emissions on human health from the STS system are only as low as those from a heat pump system through a longer operational lifetime during which the collectors must remain operational for 25 to 30 years. Emissions of respiratory inorganics, particularly particulates and sulphur dioxide, account for most of the impacts on human health from the STS and which arise predominantly from steel and copper production. The potential impacts observed for the heat pumps are also largely due to emissions of respiratory inorganics but from electricity power plants as well as from copper production used in distribution networks. The use of fossil fuels in electricity generation is therefore also an impactor on climate change which has consequences for human health. The gas and oil systems both have emissions of nitrogen oxides and sulphur dioxide associated with fuel production and transportation processes, and the combustion of the fuels releases $\mathrm{CO}_{2}$. The combustion of wood pellets emits relatively large amounts of fine particles and nitrogen oxides, and because of the lower energy density of wood pellets compared with fossil fuels, this heating system is seen to perform the worst under this damage category.

Table 6. Contribution analysis of indicators accumulated under the category Human Health

\begin{tabular}{|c|c|c|c|c|c|c|c|}
\hline \multicolumn{2}{|c|}{ Heating system } & \multirow{2}{*}{$\begin{array}{c}\begin{array}{c}\text { Carcino } \\
\text { gens (\%) }\end{array} \\
21.0 \\
\end{array}$} & \multirow{2}{*}{$\begin{array}{c}\begin{array}{c}\text { Respirator } \\
\text { y organics } \\
\text { (\%) }\end{array} \\
0.04 \\
\end{array}$} & \multirow{2}{*}{$\begin{array}{c}\begin{array}{c}\text { Respiratory } \\
\text { inorganics } \\
(\%)\end{array} \\
71.8 \\
\end{array}$} & \multirow{2}{*}{$\begin{array}{c}\begin{array}{c}\text { Climate } \\
\text { change } \\
(\%)\end{array} \\
6.7 \\
\end{array}$} & \multirow{2}{*}{$\begin{array}{c}\begin{array}{c}\text { Radiati } \\
\text { on (\%) }\end{array} \\
0.4 \\
\end{array}$} & \multirow{2}{*}{$\begin{array}{c}\begin{array}{c}\text { Ozone layer } \\
\text { depletion } \\
(\%)\end{array} \\
0.004 \\
\end{array}$} \\
\hline Solar & 40yrs 2CF & & & & & & \\
\hline & 40yrs(SA) & 21.0 & 0.04 & 71.7 & 6.8 & 0.5 & 0.004 \\
\hline & $50 \mathrm{yrs} 2 \mathrm{CF}$ & 21.0 & 0.04 & 71.7 & 6.8 & 0.5 & 0.004 \\
\hline & $60 \mathrm{yrs} 2 \mathrm{CF}$ & 21.0 & 0.04 & 71.6 & 6.9 & 0.5 & 0.004 \\
\hline & $60 y r s 3 C F$ & 23.0 & 0.04 & 71.0 & 6.0 & 0.5 & 0.004 \\
\hline & 75yrs 3CF & 23.0 & 0.04 & 70.5 & 6.0 & 0.5 & 0.004 \\
\hline \multirow{2}{*}{$\begin{array}{l}\text { Heat } \\
\text { pump }\end{array}$} & Air-source & 11.1 & 0.04 & 50.8 & 25.1 & 12.9 & 0.01 \\
\hline & Ground-srce & 10.6 & 0.05 & 52.2 & 25.0 & 12.1 & 0.1 \\
\hline \multirow[t]{2}{*}{ Fossil } & Gas & 1.5 & 0.2 & 30.4 & 67.8 & 0.2 & 0.05 \\
\hline & Oil & 2.9 & 0.2 & 51.1 & 45.5 & 0.3 & 0.03 \\
\hline Biomass & Pellets & 10.2 & 0.04 & 63.1 & 4.9 & 0.4 & 0.002 \\
\hline
\end{tabular}

\section{$4 \quad$ Discussion}

The STS is physically a very large and dominant aspect of the apartment building and it required integral design into the building from the outset. Functionally, it has been shown to be successful in meeting the heating and hot water demands throughout the year and due to the higher building standard achieved than originally planned; it is likely that the STS could supply heat to further apartments. However, the amount of infrastructure required to achieve this raised specific concerns amongst specialists in the wider community. These concerns regarded the embodied energy of the system in comparison to more 
conventional heating systems and also the justification of the investment of material resources. In respect to energy demand, the research has shown that even over a relatively short lifetime of 40 years, the total nonrenewable primary energy used in producing, operating and disposing of the STS is far lower than any of the other heating systems used in the comparison and so on this aspect the initial investment is justified (taking into consideration the assumptions made in the research). Material resource investment cannot be related to a direct pay-back during the operational lifetime but must be evaluated in relation to alternative choices. This paper applied the recycled content approach in the allocation of environmental burdens to demands for resources. Here, the processes behind producing primary and secondary (recycled) materials used in the product 'mix' are accounted for, rather than the end-of-life recycling of materials. This means that even if a material is fully recycled there will still be an allocation of primary material, and that the environmental impacts are directly linked to the product in question. An alternative method would be to assume that recycling at end-of-life avoids the extraction of further primary resources and that the benefits of this can be credited to the initial product (avoided burden approach). This method was not used because it predicts a level of future recycling which it depends upon in order to discount actual environmental burdens from the production and use of the product. This also has the effect of allowing for the substitution of resources in the eco-sphere with those in the techno-sphere, thus following the concept of weak sustainability. A comparison of allocation procedures in connection with recycling has been conducted by Frischknecht [32].

The STS may well achieve a longer operational lifetime, within which time an alternative would be periodically replaced so that the validity of the initial investment depends on the overall demand reflected by the alternatives. As has been shown, this is not only for manufacturing stages but also for the operation due to the requirement for exterior infrastructures associated with electricity or fuel supply. If all major components of the STS could achieve the same lifetime and one which reflected the lifetime of the building, then the physical material investments could become competitive with those of an alternative when viewed on a per MJ useful heat basis. Unfortunately however, the solar collectors will need to be exchanged during the system lifetime and their resource demand is very significant in relation to the whole STS.

The third indicator of popular and vital concern is the lifetime GHG emissions and on which the STS performs better than most others but with less of an interval than for non-renewable primary energy demand. With reference to the heat pumps this is benefitially influenced by the electricity supply mix in Switzerland which is largely from nuclear and hydro power plants, and only around 10\% from fossil fuels. 
This work compared a $100 \%$ solar heating system recently installed in a Swiss apartment building with five alternative heating systems on the basis of life cycle assessment. Applying the recycled content allocation procedure, the results for the STS lifetime scenarios clearly show the benefits of extended lifetimes of both storage vessel and collector field. The overall reduced life-cycle impacts of a 60 year system lifetime requiring either 2 or 3 collector fields highlights the significant influence that the collector field has on the level of potential impacts. Indeed, for the majority of the life-cycle indicators, it was determined that the solar collectors are responsible for a larger share of the potential impacts than the storage vessel.

The results for the STS show relatively little variation between the scenarios with regard to cumlative energy demand and greenhouse gas emissions. In contrast the potential impacts on abiotic resource use, ecosystem quality and human health change from being less favourable under shorter system lifetimes to more favourable under longer system lifetimes. However it is also not always the case that a longer system lifetime will give consistently better results. For example, the potential impacts on ecosystem quality from a 75 year lifetime $\left(0.0026 \mathrm{PDFm}^{2} \mathrm{a} / \mathrm{MJ}\right)$ are greater than those of 60 year lifetime with 2 collector fields $(0.0024$ $\mathrm{PDFm}^{2} \mathrm{a} / \mathrm{MJ}$ ) due to the significant impacts associated with continued replacement of the solar collector field. The electricity used during the construction and disposal stages of the STS (investigated through doubling the electricity consumed in the 40yrs $2 \mathrm{CF}$ (SA) scenario) had minimal influence on all the impact indicators.

The CED results show the potential reductions in non-renewable primary energy use associated with the complete life cycle of the STS as well as the reductions in primary energy needing to be purchased, and therefore generated (Figure 2). The STS could reduce the purchased primary energy by a minimum of $84 \%$ to a maximum of $93 \%$ in comparison with the other heating systems. Wood pellet fuel comprises of $81 \%$ of the primary energy used in the life cycle of the wood pellet system and so indicates a potentially small requirement for centralised sources of energy (nuclear and fossil) for the wood pellet system in comparison with the heat-pumps and fossil fuelled systems.

The STS uses significantly higher amounts of non-combustable abiotic resources by factors ranging from 3.8 in comparison to the air-source heat pump to 38 in comparison to the gas heating system (Figure 3). Although a longer system lifetime noticeably improves this in relation to $1 \mathrm{MJ}$ of heat output, the trend shows that it would require an operational lifetime of several hundred years in order to achieve results competitive with the alternative systems. GHG emissions associated with all the STS scenarios were shown to be lower than for the heat pumps and far lower than the gas and oil systems (Figure 4). Comparing all scenarios and heating systems (with exception to the wood pellet system) the STS could reduce GHG 
emissions by a minimum of $59 \%$ to a maximum of $97 \%$. The analysis of the wood pellet system considered the biogenic cycle to be carbon-neutral and therefore the GHG emissions from this system were seen to be similar to the STS. With around $57 \%$ of total impacts ecotoxicity is the most significant indicator of ecosystem quality for the STS of which copper used in the collectors accounts for more than $90 \%$. All STS scenarios have higher values than either the heat pumps or the fossil fuel systems. The heat pump systems show higher impacts than the gas heating system and similar levels to the oil heating system due to heavy metal emissions from the electricity distribution network. Damage to human health is characterised by a number of indicators for which respiratory inorganics and climate change were the most dominant for all heating systems. For the human health indicator the longer STS scenarios are competitive with the heat pumps whilst all STS scenarios show the potential to be better than the fossil and wood-pellet fuelled systems.

Therefore, if higher importance is placed on primary energy demand and GHG emissions then the STS has a very clear advantage over the heat pumps and the fossil fuel systems regardless of which lifetime scenario is chosen, although it would be only marginally better than the wood pellet system. If the depletion of abiotic resources is also considered to be a valuable indicator then the wood pellet system is clearly more favourable than the STS which is, by a significant margin, the most damaging under this indicator.

\section{References}

[1] A. Pfeiffer, M. Koschenz, A. Wokaun, Energy and building technology for the 2000 W Society - Potential of residential buildings in Switzerland, Energy and Buildings 37 (2005) 1158-1174.

[2] P. Kesselring, CJ. Winter, Energietage; World Energy Scenarios: A Two-Kilowatt Society - Plausible Future or Illusion? Villigen, Paul Scherrer Institut (PSI), 1994.

[3] F. Marechal, D. Favrat, E. Jochem, Energy in the perspective of sustainable development: The $2000 \mathrm{~W}$ society challenge. Resources, Conservation and Recycling 44 (3) (2005) 245-262.

[4] M. Koschenz, A. Pfeiffer, Potenzial Wohngebäude; Energie und Gebäudetechnik für die 2000-WattGesellschaft. Zürich, Faktor Verlag, 2005.

[5] J-C. Hadorn, International Energy Agency Solar Heating \& Cooling Programme; Thermal energy storage for solar and low energy buildings - State of the art. IEA Solar Heating and Cooling Programme. Task 32. Lleida, Edicions de la Universitat de Lleida, 2005.

[6] The MINERGIE-Standard for Buildings; information for architects.

http://www.minergie.ch/tl files/download en/Faltblatt Minergie Standard e.pdf 
[7] SIA 380/1. Thermische Energie im Hochbau. Zürich, Schweizerischer Ingenieur- und Architekten- Verein (SIA), 2007.

[8] J. Smeds, M. Wall, Enhanced energy conservation in houses through high performance design, Energy and Buildings 39 (3) (2007) 273-278.

[9] C. Joika, P. Rubeck, G. Dasch, W. Hilz, I. Röpcke, A. Schuster, Das Sonnenhaus: Unabhangig und umwelt bewusst wohnen mit der Sonne. Straubing, Sonnenhaus-Institut, 2009.

[10] J. Jenni, Sonnenenergieanlagen mit hohem solarem Deckungsgrad für Warmwasser und Heizung. Oberburg, Jenni Energietechnik AG, 1996.

[11] C.J. Swet, Storage Concepts and Design. in: F. DeWinter (Ed.), Solar Collectors, Energy Storage and Materials. MIT Press, 1990, pp. 625-691.

[12] F.J. Rey-Martínez, E. Velasco-Gómez, J. Martín-Gil, L.M. Navas Gracia, S. Hernández Navarro, Life Cycle Analysis of a Thermal Solar Installation at a Rural House in Valladolid (Spain), Environmental Engineering Science, 25 (5) (2008) 713-724.

[13] N Taoussanidis, Life Cycle Assessment of Combined Solar System, Proceedings of the 4th WSEAS Int. Conf. on Heat Transfer, Thermal Engineering and Environment, Elounda, Greece, August 21-23 (2006) 7477.

[14] S. A. Kalogirou, Environmental benefits of domestic solar energy systems, Energy Conversion and Management 45 (2004) 3075-3092.

[15] S.R. Allen, G.P. Hammonda, H.A. Harajli, M.C. McManus, A.B. Winnett, Integrated appraisal of a Solar Hot Water system, Energy 35 (2010) 1351-1362

[16] Jenni Energietechnik AG. Heizen nur mit sonne: Das Oberburger Sonnenhaus. http://www.jenni.ch/html/Heizen\%20mit\%20Sonne/Sonnenhaus/Sonnenhaus.htm, 2009.

[17] J.R. Hull, Analytical and Numerical Modeling of Thermal Energy Storage. in: F. DeWinter (Ed.), Solar Collectors, Energy Storage and Materials. MIT Press, 1990, pp. 692-730.

[18] ISO 14040. Environmental management - Life cycle assessment - Principles and framework. Geneva, International Organisation for Standardisation (ISO), 2006.

[19] MeteoSchweiz. Normwert-Tabellen 1961-1990.

http://www.meteoschweiz.admin.ch/web/de/klima/klima schweiz/tabellen.html

[20] S. Mennel, U-P. Menti, G. Notter, MINERGIE-P; A Building Standard of the Future. Proceedings of Clima 2007 Wellbeing Indoors, 2007.

[21] ecoinvent Centre (2007) The ecoinvent LCA database - ecoinvent data v2.0. Swiss Centre for Life Cycle Inventories, Dübendorf, Switzerland. online: www.ecoinvent.org 
[22] P. Konttinen, PD. Lund, Thermal stability and moisture resistance of $\mathrm{C} / \mathrm{Al}_{2} \mathrm{O}_{3} / \mathrm{Al}$ solar absorber surfaces. Solar Energy Materials and Solar Cells, 82 (3) (2004) 361-373.

[23] M. Köhl, M. Heck, S. Brunold, U. Frei, B. Carlsson, K. Möllerk, Advanced procedure for the assessment of the lifetime of solar absorber coatings. Solar energy materials and solar cells, 84 (3) (2004) 275-289.

[24] Jenni Energietechnik AG. Heizen nur mit sonne: Technische Daten. http://www.jenni.ch/, 2009.

[25] SIA 381/2. Klimadaten zu Empfehlung 380/1 „Energie im Hochbau“. Zürich, Schweizerischer Ingenieurund Architekten- Verein (SIA), 1988.

[26] R. Frischknecht, N. Jungbluth, HJ. Althaus, G. Doka, T. Heck, S. Hellweg, R. Hischier, T. Nemecek, G. Rebitzer, M. Spielmann, Ecoinvent report No. 1, v2.0; Overview and Methodology. Dübendorf, Swiss Centre for Life Cycle Inventories, 2007.

[27] M. Geodkoop, A. De Schryver, M. Oele, Introduction to LCA with SimaPro 7. Amersfoort, PRé Consultants B.V, 2008.

[28] R. Frischknecht, N. Jungbluth, HJ. Althaus, C. Bauer, G. Doka, R. Dones, R. Hischier, S. Hellweg, S. Humbert, T. Köllner, Y. Loerincik, M. Margni, T. Nemecek, Implementation of Life Cycle Impact Assessment Methods. Ecoinvent report No. 3, v2.0. Dübendorf, Swiss Centre for Life Cycle Inventories, 2007. [29] J.B. Guinée, M.Gorrée, R.Heijungs, G. Huppes, R. Kleijn, A. de Koning, L. van Oers, A. Wegener Sleeswijk, S. Suh, H.A. Udo de Haes, H. de Bruin, R. van Duin, M.A.J. Huijbregts (2001) LCA -An operational guide to the ISO standards - Part 2b: Operational annex. Centre of Environmental Science, Leiden University (CML).

[30] S. Solomon, D. Qin, M. Manning, RB. Alley, T. Berntsen, NL. Bindoff, Z. Chen, A. Chidthaisong, JM. Gregory, GC. Hegerl, M. Heimann, B. Hewitson, BJ. Hoskins, F. Joos, J. Jouzel, V. Kattsov, U. Lohmann, T. Matsuno, M. Molina, N. Nicholls, J. Overpeck, G. Raga, V. Ramaswamy, J. Ren, M. Rusticucci, R. Somerville, TF. Stocker, P. Whetton, RA. Wood, D. Wratt, Technical Summary. in: Climate Change 2007: The Physical Science Basis. Contribution of Working Group I to the Fourth Assessment Report of the Intergovernmental Panel on Climate Change. Cambridge University Press, 2007.

[31] M. Goedkoop, R. Spriensma, The eco-indicator 99; A damage orientated method for life cycle impact assessment: Methodology Report. Amersfoort, PRé Consultants B.V, 2000.

[32] R.Frischknecht, LCl modelling approaches applied on recycling of materials in view of environmental sustainability, risk perception and eco-efficiency, Int J Life Cycle Assessment 15 (2010) 666-671. 